\title{
Impaired cell death and mammary gland involution in the absence of Dock1 and Rac1 signaling
}

\author{
H Bagci ${ }^{1,2}$, M Laurin ${ }^{1}$, J Huber ${ }^{1}$, WJ Muller ${ }^{3}$ and J-F Côtée,1,2,4,5
}

Throughout life, the tight equilibrium between cell death and the prompt clearance of dead corpses is required to maintain a proper tissue homeostasis and prevent inflammation. Following lactation, mammary gland involution is triggered and results in the death of excessive epithelial cells that are rapidly cleared by phagocytes to ensure that the gland returns to its prepregnant state. Orthologs of Dock1 (dedicator of cytokinesis 1), Elmo and Rac1 (ras-related C3 botulinum toxin substrate 1) in Caenorhabditis elegans are part of a signaling module in phagocytes that is linking apoptotic cell recognition to cytoskeletal reorganization required for engulfment. In mammals, Elmo1 was shown to interact with the phosphatidylserine receptor Bai1 and relay signals to promote phagocytosis of apoptotic cells. Still, the role of the RacGEF Dock1 in the clearance of dying cells in mammals was never directly addressed. We generated two mouse models with conditional inactivation of Dock1 and Rac1 and revealed that the expression of these genes is not essential in the mammary gland during puberty, pregnancy and lactation. We induced mammary gland involution in these mice to investigate the role of Dock1/Rac1 signaling in the engulfment of cell corpses. Unpredictably, activation of Stat3 (signal transducer and activator of transcription 3), a key regulator of mammary gland involution, was impaired in the absence of Rac1 and Dock1 expression. Likewise, failure to activate properly Stat3 was coinciding with a significant delay in the initiation and progression of mammary gland involution in mutant animals. By using an in vitro phagocytosis assay, we observed that Dock1 and Rac1 are essential to mediate engulfment in epithelial phagocytes. In vivo, cell corpses accumulated at late time points of involution in Dock1 and Rac1 mutant mammary glands. Overall, our study demonstrated an unsuspected role for Dock1/Rac1 signaling in the initiation of mammary gland involution, and also suggested a role for this pathway in the clearance of dead cells by epithelial phagocytes.

Cell Death and Disease (2014) 5, e1375; doi:10.1038/cddis.2014.338; published online 14 August 2014

Programmed cell death is essential for embryonic development by contributing to tissue remodeling and elimination of transient cells such as during digit formation. ${ }^{1}$ Prompt clearance of apoptotic cells is necessary to prevent cellular leakage that could induce autoimmune reactions. ${ }^{2} \mathrm{~A}$ key 'eatme' signal of apoptotic cells, phosphatidylserine (PtdSer), is exposed on the outer leaflet of the plasma membrane and facilitates their rapid recognition by phagocytes. Pioneering work in Caenorhabditis elegans identified genes expressed in phagocytes that mediate apoptotic cell clearance including orthologs of Dock1 (dedicator of cytokinesis 1), Elmo and Rac, but whether this signaling module is universal for phagocytosis of dead corpses is poorly explored. ${ }^{3}$

In vitro studies suggested that signaling by the RacGEF Dock1 and its binding partners Elmo1 and Crkll is required for phagocytosis in mammalian cells. ${ }^{4-7} \mathrm{~A}$ Crkll/Dock1 complex is recruited to $\alpha v \beta 5$ integrin to promote phagocytosis. ${ }^{4}$ It remains unclear if a direct binding of Crkll to Dock1 is needed for engulfment. ${ }^{7}$ Overexpression of Elmo1 and Dock1 in cells increases their engulfment capacity. ${ }^{5}$ In addition, bridging of PtdSer on apoptotic cells by the phagocyte-secreted glycoprotein Mfge8 facilitates binding of the target cells to $\alpha v \beta 5$ integrin to recruit Dock1-Crkll for engulfment in epithelial cells. ${ }^{6}$ Bai1 was defined as a phagocytic receptor via its ability to couple apoptotic cell recognition to Rac-dependent cytoskeletal changes. ${ }^{8}$ The generation of an Elmo1-knockout model demonstrated the importance of this protein in the removal of dying cells in vivo. ${ }^{9,10}$

The regulation of cell death initiation coupled to the removal of cell corpses is an integral part of the mammary gland life cycle. ${ }^{11}$ During pregnancy, epithelial cells of the mammary gland expand to form branched and lobuloalveolar structures, while adipocytes dedifferentiate to allow milk production after birth of the offspring. Upon weaning of the progeny, the mammary gland undergoes an important remodeling step, termed involution, during which the unessential mammary epithelial cells (MECs) die and are largely removed by nonprofessional phagocytes, that is, the epithelium itself. ${ }^{12}$ Professional phagocytes, such as macrophages, also contribute to dead cell engulfment during involution. ${ }^{13}$ The adipocytes repopulate the gland and the extracellular matrix is reorganized such that the mammary gland returns to its prepregnant state to start a new cycle. ${ }^{11}$ Involution is a tightly regulated process that can be separated into two phases.

\footnotetext{
${ }^{1}$ Institut de Recherches Cliniques de Montréal (IRCM), Montréal, QC, Canada; ${ }^{2}$ Department of Anatomy and Cell Biology, McGill University, Montréal, QC, Canada; ${ }^{3}$ Goodman Cancer Centre, McGill University, Montréal, QC, Canada; ${ }^{4}$ Département de Biochimie et Médecine Moléculaire, Université de Montréal, Montréal, QC, Canada and ${ }^{5}$ Département de Médecine (Programmes de Biologie Moléculaire), Université de Montréal, Montréal, QC, Canada

*Corresponding author: J-F Côté, Institut de Recherches Cliniques de Montréal (IRCM), 110 Pine Avenue Ouest, Montréal, QC, H2W 1R7 Canada. Tel: +1 514987 5647; Fax: +1 514987 5624; E-mail: jean-francois.cote@ircm.qc.ca

Abbreviations: Dock1, dedicator of cytokinesis 1; Rac1, ras-related C3 botulinum toxin substrate 1; Stat3, signal transducer and activator of transcription 3; NMuMG, normal murine mammary gland; TUNEL, terminal deoxynucleotidyl transferase dUTP nick-end labeling

Received 11.12.13; revised 08.7.14; accepted 09.7.14; Edited by H-U Simon
} 
The first phase, approximately 2 days and reversible, is characterized by the shedding of epithelial cells in the lumen of ducts. The second and irreversible phase is characterized by the secretion of active metalloproteases and the recruitment of macrophages to assist the MECs in removing dying cells. ${ }^{14}$

Signals promoting the initiation of involution converge toward the activation of the transcription factor Stat3 (signal transducer and activator of transcription 3) that is critical such that involution is delayed in the absence of its expression. ${ }^{15}$ The secreted factor Lif contributes to Stat3 activation in the gland during the first phase of involution to promote cell death through a lysosomal-mediated pathway. ${ }^{16}$ Activation of Stat3 by Lif leads to an upregulation of the Oncostatin receptor that promotes Stat3 activation in the second phase of involution by engaging its ligand Oncostatin. ${ }^{17}$ During this latter period, Stat3 uniquely promotes the death of MEC through apoptosis. While Stat3 activation in the mammary gland induces a specific gene response, the mechanisms governing Stat3 activation remain poorly defined. ${ }^{17-19}$

The molecular pathways implicated in the clearance of dying epithelial cells are being unraveled. The PtdSerglycoprotein Mfge8 decorates dying epithelial cells for rapid clearance by phagocytes during involution. ${ }^{20,21}$ The molecular intermediates necessary for engulfment during involution remain largely uncharacterized. Here, we investigated the role of Dock1/Rac1 (ras-related C3 botulinum toxin substrate 1) in the clearance of epithelial cells during mammary gland involution. By using mouse models with inactivation of Dock1 and Rac1 in mammary gland epithelial cells, we reveal an unsuspected role for these genes in the activation of Stat3 during involution, which coincide with a delay in the initiation of mammary gland involution. Moreover, we observed that Dock1 and Rac1 mediate engulfment of apoptotic corpses by epithelial phagocytes.

\section{Results}

Ablation of Dock1 and Rac1 in the mammary gland. Orthologs of Dock1, Elmo and Rac are part of one of two signaling cascades that control engulfment in $C$. elegans. ${ }^{3}$ We generated mice with inactivation of Dock1 and Rac1 in the mammary gland epithelial compartment by crossing animals carrying floxed $(f / x)$ alleles of these genes with $\mathrm{MMTVCre}^{+}$transgenic mice to examine their roles during cell clearance using mammary gland involution as an experimental model. We confirmed that expression of Cre led to the recombination of the Rac1 and Dock1 flx alleles in the mammary gland (Supplementary Figures S1a and S1b) and that Rac1 and Dock1 are expressed in wild-type mammary glands at lactation day 10 (Figures 1a and 2a). Importantly, we observed that Cre-mediated genetic ablation of Rac1 and Dock1 reduced their levels of expression in the mammary glands of MMTVCre ${ }^{+} \mathrm{Rac}^{f \mid x / f l x}$ and MMTVCre ${ }^{+}$ Dock $1^{\text {flX } / f l x}$ animals, respectively, as verified by western blot (Figures 1a and 2a).

Rac1 and Dock1 mutant mice have normal mammary gland development. Before addressing the importance of Dock1 and Rac1 in cell clearance during involution, we investigated whether these genes are required during mammary gland puberty, pregnancy and lactation. The role of Dock1 during mammary gland development was previously assessed and it was shown that it is not required for proper mammary gland development. ${ }^{22}$ Whole-mount mammary gland outgrowth analyses of MMTVCre ${ }^{+}$Rac $^{\text {wt }}{ }^{\text {wt }}$ and MMTVCre $^{+} \mathrm{RaC1}^{f l x / f l x}$ animals at 9, 12 and 15 weeks confirmed that Rac1 is not required for mammary gland development during puberty (Supplementary Figure S2). Furthermore, whole-mount analyses confirmed that Dock1 and Rac1 are not required for mammary gland remodeling during pregnancy (Supplementary Figure S3). To exclude the possibility that Dock1 and Rac1 are required for the progression to the lactating state, we stained Lac10 (10 days of lactation) glands of both genotypes for the lactation marker pStat5. ${ }^{23}$ These analyses demonstrated a robust activation of Stat5 in epithelial cell in both Dock1 and Rac1 mutants that was comparable to control glands (Supplementary Figure S4). The staining of pStat5 was rapidly lost upon entering the involution state (Supplementary Figure S4). Whole-mount staining of Lac10 glands demonstrated an identical gross morphology for both genotypes in comparison with controls (data not shown). Both MMTVCre ${ }^{+} \operatorname{Rac1}^{f / x / f I x}$ and MMTVCre ${ }^{+}$Dock $1^{f l x / f l x}$ models were fertile. In addition, pups derived from MMTVCre ${ }^{+} \operatorname{Rac1}^{f l x / f l x}$ and MMTVCre ${ }^{+}$Dock $1^{f l x / f l x}$ females were viable and reached adulthood without any signs of deterioration in health or weight. These results confirm the normal lactating state of Dock1 and Rac1 mutant animals. We investigated by semiquantitative RT-PCR if the expression of Rac1 or Dock1 is regulated during involution. We found that these genes are expressed during both lactation and involution (Supplementary Figure S5).

Adipocyte repopulation is delayed in Rac1 and Dock1 mutant mice. To investigate the role of Rac1 during involution, pups were removed from the nursing mother after Lac10 to induce involution in a synchronous manner. Histologic analysis was carried on in $M M T V C r{ }^{+}$Rac1 $^{\text {wt }}$ wt and MMTVCre ${ }^{+} \operatorname{Rac1}^{f(x / f l x}$ animals to observe the progression of morphologic changes after 0 to 4 days of forced involution (Lac10, Inv1, Inv2, Inv3 and Inv4). At Lac10, majority of the gland in MMTVCre ${ }^{+} \mathrm{Rac1}^{\mathrm{wt} / \mathrm{wt}}$ and MMTVCre ${ }^{+} \operatorname{Rac1}^{f l x / f l x}$ animals was composed of alveolar structures filled with milk produced by the epithelial cells and no difference was observed between genotypes, which correlates with the ability of mutants mice to nurse their progeny (Figure 1b). After 1 day of involution, and more noticeable after 2 days, fat cell repopulation could be observed in the mammary gland parenchyma of MMTVCre ${ }^{+}$ Rac1 ${ }^{w t / w t}$ animals (Figure 1b). Unexpectedly, the mammary glands of $M M T V C r{ }^{+} R_{a c 1}{ }^{f l x f f x}$ animals retained the appearance of a lactating gland after 1 day of involution (Figure 1b). The presence of adipocytes could be detected after 2 days of involution but was significantly delayed in the absence of Rac1 expression (Figure 1b). These results were confirmed by detecting adipocytes with anti-Perilipin, a marker protein found in fat droplets ${ }^{24}$ (Figure 1d). Notably, adipocytes accounted for only a small fraction of cells, present in same quantities, in both genotypes at Lac10. Quantification of the area occupied by adipocytes in the mammary glands of 


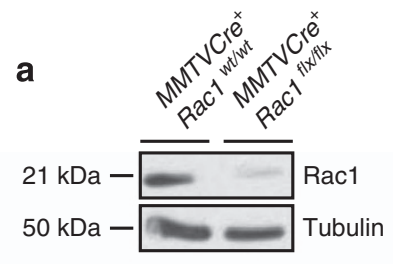

b

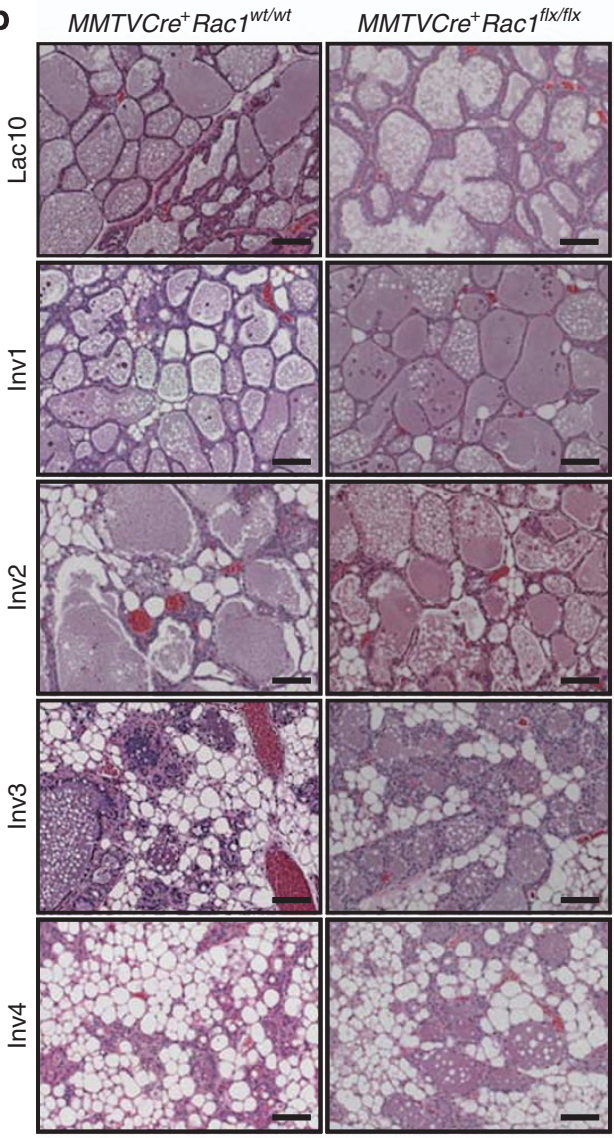

C

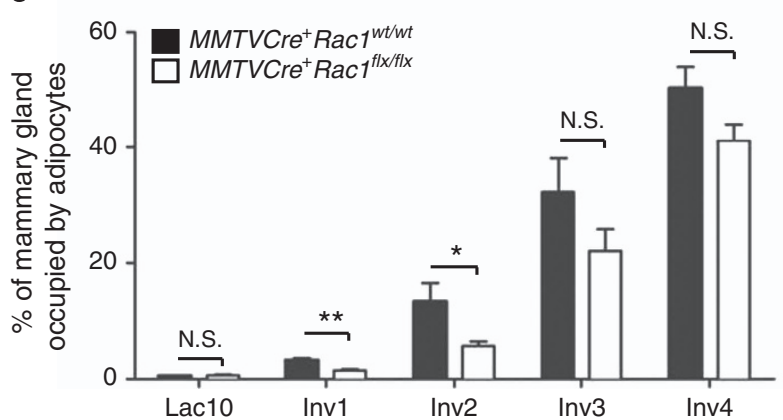

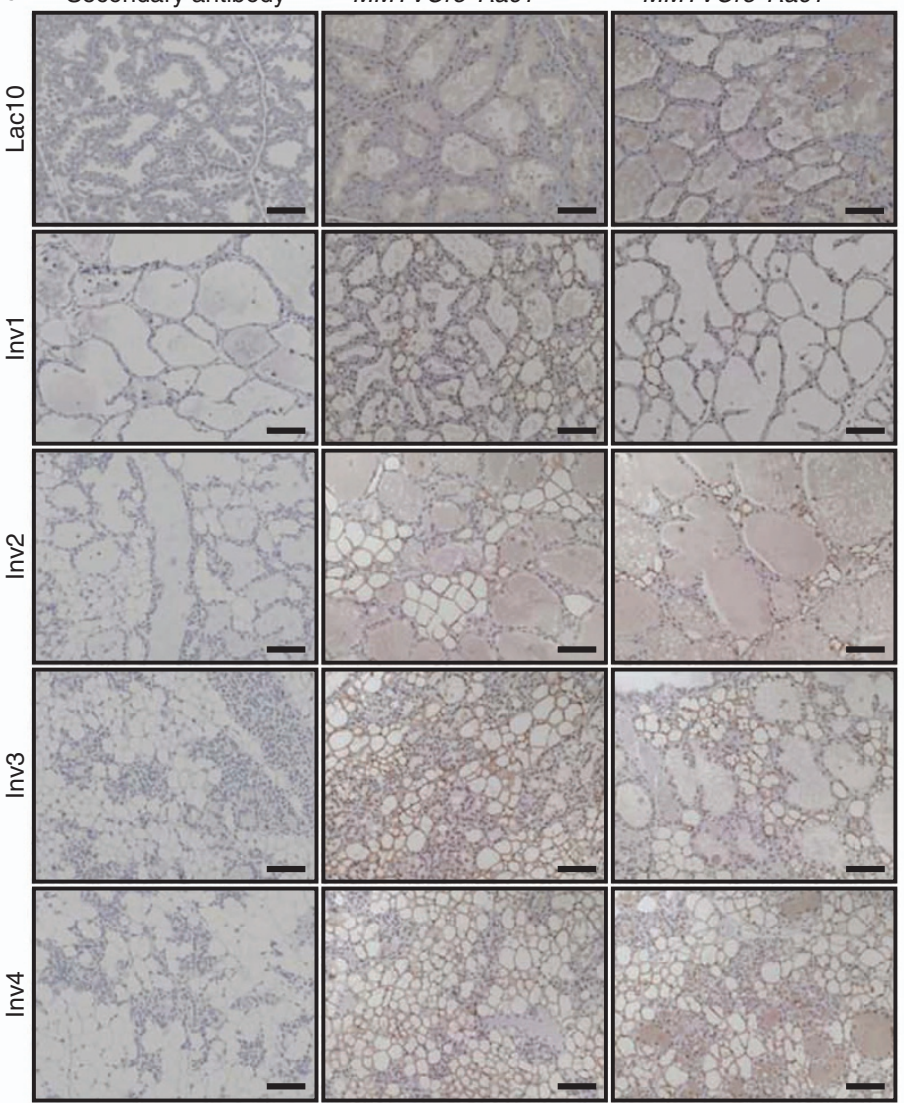

e

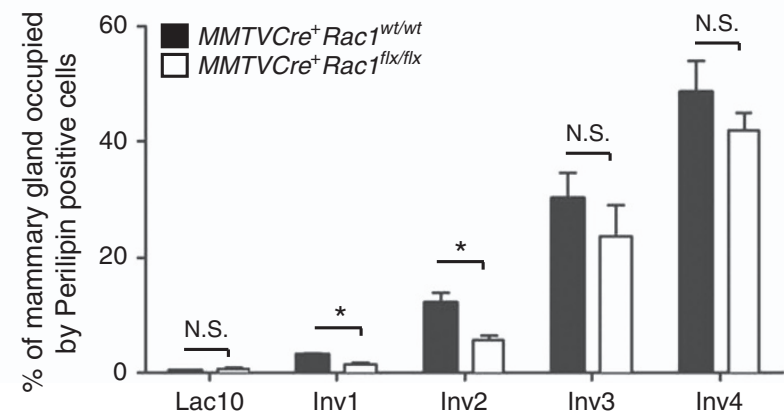

Figure 1 Mammary gland involution is delayed in MMTVCre ${ }^{+}$Ract $1^{f l f f l x}$ mice. (a) Western blot analysis demonstrating the absence of Rac1 expression in Lac10 mammary glands of MMTVCre ${ }^{+}$Ract $^{\text {flx } x \text { flx }}$ mice. (b) H\&E staining of mammary glands at 10 days of lactation and after $1,2,3$ or 4 days of involution showing delayed repopulation of adipocytes in MMTVCre ${ }^{+}$Ract $^{f(x f f l x}$ mice (scale bar: $100 \mu \mathrm{m}, \times 20$ ). (c) Average percentage of the area occupied by adipocytes at the indicated lactation and

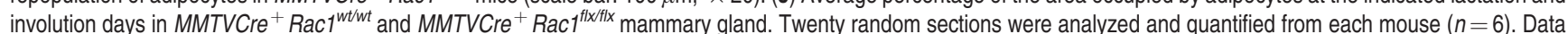
were shown as mean \pm S.E.M. The indicated $P$-values were calculated by using a two-tailed Student's $t$ test. NS, not significant, ${ }^{*} P \leq 0.05$ and ${ }^{* *} P \leq 0.01$. (d) IHC analysis showing Perilipin staining in mammary glands at 10 days of lactation and after 1, 2, 3 and 4 days of involution showing delayed repopulation of adipocytes in

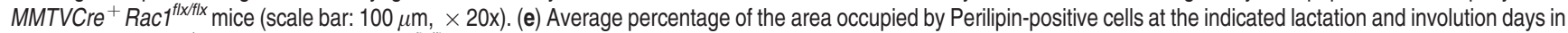

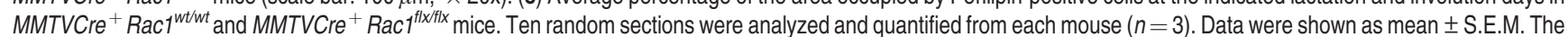
indicated $P$-values were calculated by using a two-tailed Student's $t$ test. ${ }^{*} P \leq 0.05$ 


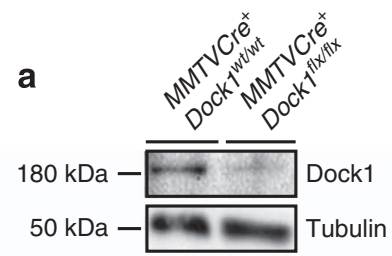

b

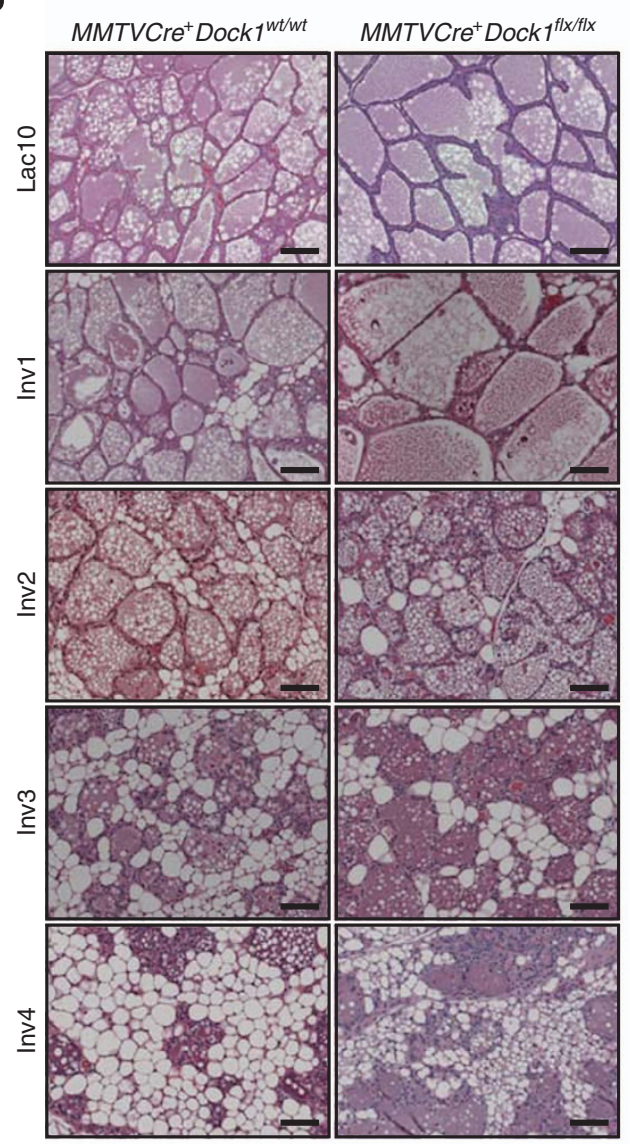

d

Secondary antibody MMTVCre Dock $1^{\text {wt/wt }} \quad$ MMTVCre Dock $1^{\text {flx } / f l x}$

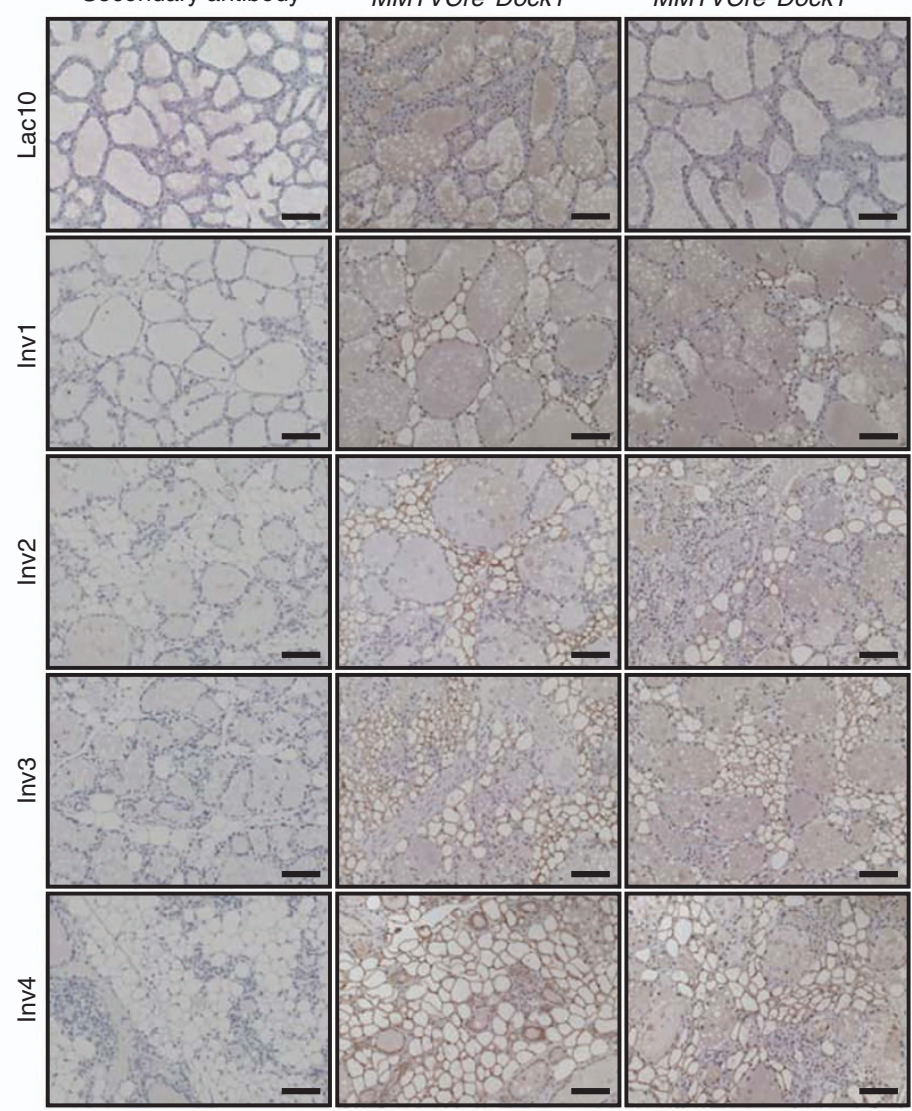

C

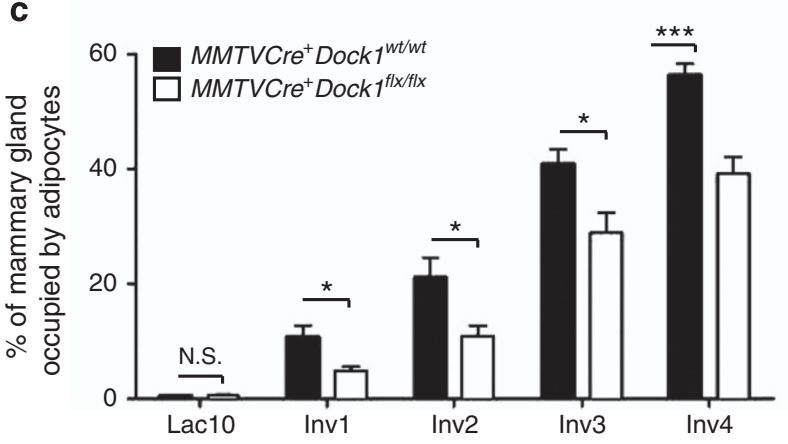

e

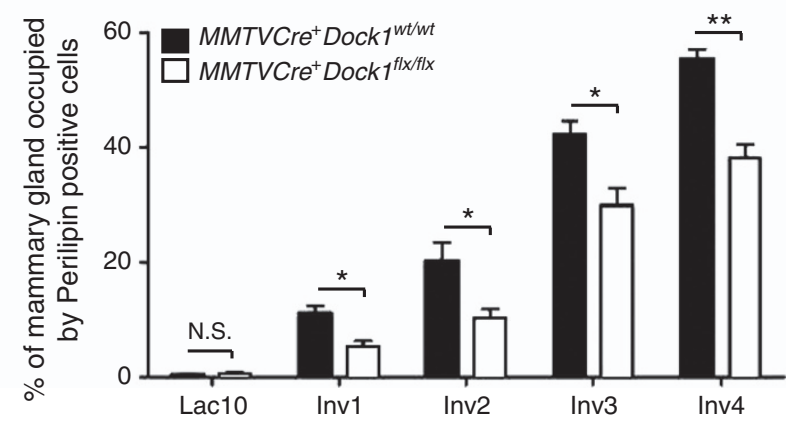

Figure 2 Mammary gland involution is delayed in MMTVCre ${ }^{+}$Dock $1^{f l x}$ fllx mice. (a) Western blot analysis demonstrating the absence of Dock1 expression in Lac10 mammary glands of MMTVCre ${ }^{+}$Dock $1^{f / x f l x}$ mice. (b) H\&E staining of mammary glands at 10 days of lactation and after 1, 2, 3 or 4 days of involution showing delayed repopulation of adipocytes in MMTVCre ${ }^{+}$Dock $1^{f l x}$ flx mice (scale bar: $\left.100 \mu \mathrm{m}, \times 20\right)$. (c) Average percentage of the area occupied by adipocytes at the indicated lactation and involution days in MMTVCre ${ }^{+}$Dock $1^{\text {wt } / w t}$ and MMTVCre ${ }^{+}$Dock $1^{\text {flx } / f l x}$ mammary gland. Twenty random sections were analyzed and quantified from each mouse $(n=6)$. Data were shown as mean \pm S.E.M. The indicated $P$-values were calculated by using a two-tailed Student's $t$-test. NS, not significant, ${ }^{*} P \leq 0.05$ and ${ }^{\star \star \star} P \leq 0.001$. (d) IHC analysis showing Perilipin staining in mammary glands at 10 days of lactation and after 1, 2, 3 and 4 days of involution showing delayed repopulation of adipocytes in

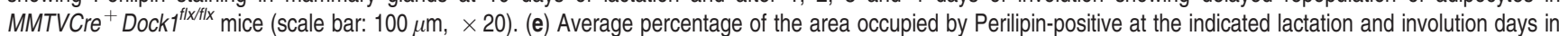
MMTVCre ${ }^{+}$Dock $1^{\text {wtwt }}$ and MMTVCre ${ }^{+}$Dock $1^{f l}$ fflx mice. Ten random sections were analyzed and quantified from each mouse $(n=3)$. Data were shown as mean \pm S.E.M. The indicated $P$-values were calculated by using a two-tailed Student's $t$-test. NS, not significant, ${ }^{*} P \leq 0.05$ and ${ }^{* *} P \leq 0.01$ 
$\mathrm{MMTVCre}^{+} \mathrm{Rac}^{\text {wt/wt }}$ and MMTVCre ${ }^{+} \mathrm{Rac}^{\text {flx/flx }}$ animals at the indicated time points further confirmed the presence of a delay in the initiation of involution in mutant animals (Figures 1c and e).

Similarly, the progression of involution was studied in MMTVCre ${ }^{+}$Dock $1^{\text {wt/wt }}$ and MMTVCre ${ }^{+}$Dock $1^{\text {flx/flx }}$ animals. At Lac10, the majority of the gland in MMTVCre ${ }^{+}$Dock $1^{\text {wt/wt }}$ and $M M T V C r{ }^{+}$Dock $1^{f l x / f l x}$ animals was composed of alveolar structures filled with milk and no difference was observed between genotypes (Figure $2 b$ ). After 1 and 2 days of involution, repopulation of the mammary gland by adipocytes was observed in control animals (Figure 2b). The mammary gland of $M M T V C r e^{+} D o c k 1^{f l x / f l x}$ animals retains the appearance of a lactating gland after 1 day of involution (Figure 2b). Moreover, a delay in the re-emergence of adipocytes in the gland was observed at all time points analyzed in Dock1 mutants (Figure 2b). No difference in adipocytes was detected between genotypes at Lac10. These results were confirmed when adipocytes were stained with anti-Perilipin (Figure 2d). Quantification of the area occupied by adipocytes in the mammary glands of MMTVCre ${ }^{+}$Dock $1^{\text {wt/wt }}$ and MMTVCre ${ }^{+}$Dock $1^{\text {flx/flx }}$ animals confirmed the significant delay observed in the initiation and progression of involution in the absence of Dock 1 expression (Figures $2 \mathrm{c}$ and e). Collectively, these results revealed an unsuspected requirement of Dock1 and Rac1 for the initiation of mammary gland involution.

Dock1 and Rac1 are required to activate Stat3 during involution. Activation of the transcription factor Stat3 is essential to initiate involution. ${ }^{25}$ Notably, mammary gland involution is delayed in Stat3 mutants. ${ }^{15}$ We previously reported that Stat3 activation is reduced in mammary neoplastic lesions induced by the HER2/Neu oncogene in Dock1 mutant mice. ${ }^{22}$ We hypothesized that a failure to maximally activate Stat3 upon milk accumulation in the mammary gland could contribute to the involution delays observed in the absence of Rac1 and Dock1 expression. We investigated the phosphorylation status of Stat3 during involution in control and mutant animals by performing immunohistochemisty (IHC) and immunofluorescence (IF) analyses. Stat3 activation, measured by detecting phospho (p)-Stat ${ }^{\mathrm{Y} 705}$, was induced and sustained in MECs after 1 and 2 days of involution (first phase of involution) in MMTVCre ${ }^{+} \mathrm{Rac1}^{\text {wt/wt }}$ mammary glands with a marked decrease at Inv3 and Inv4 (Figure 3a). In contrast, Stat3 phosphorylation was low in MMTVCre ${ }^{+} \operatorname{Rac}^{f \mid x / f l x}$ MECs after 1 and 2 days of involution and instead peaked at Inv4 (Figure 3a). These results were confirmed by staining for p-Stat3 by IF (Supplementary Figures S6 and S7); however, we observed by IF that the signal for $\mathrm{p}$-Stat3 and Hoechst-stained nuclei does not always perfectly overlap. Quantification of the number of p-Stat3-positive cells normalized on the total number of nuclei further confirmed this delay (Figure $3 \mathrm{~b}$ and Supplementary Figure S7).

Levels of Stat3 activation were evaluated in mammary glands derived from MMTVCre ${ }^{+}$Dock $1^{w t / w t}$ and MMTVCre ${ }^{+}$ $D o c k 1^{f / x / f l x}$ animals after synchronous removal of the pups for the indicated times. Stat3 activation was induced and sustained in MECs after 1 and 2 days of involution in control

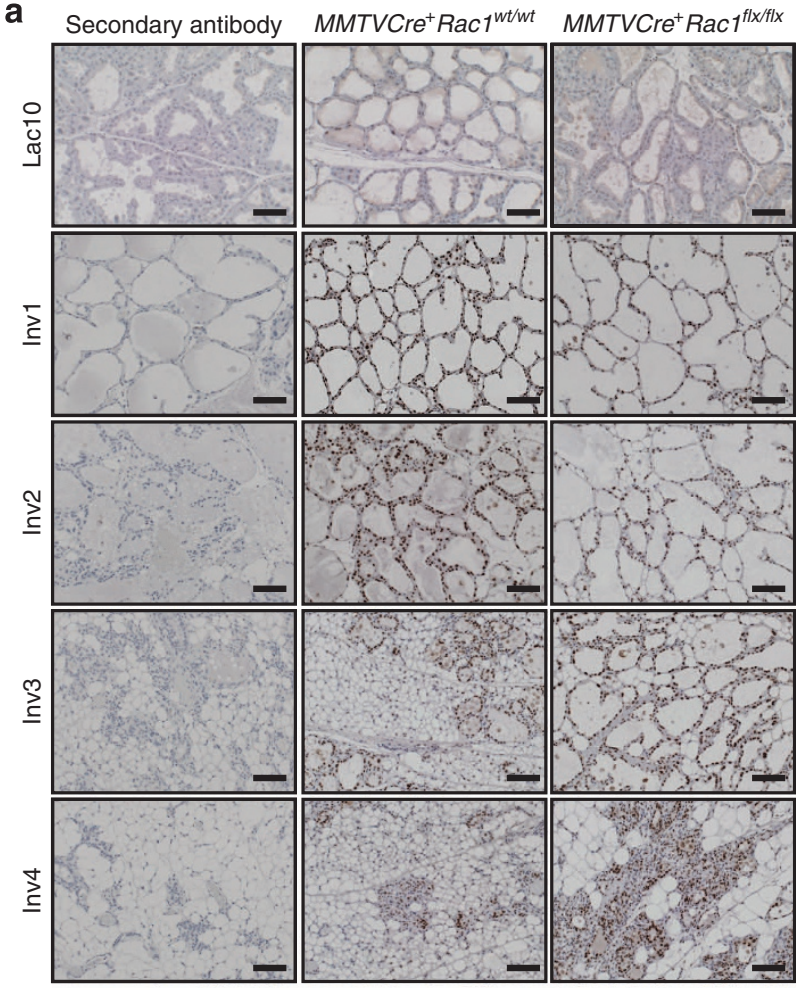

b

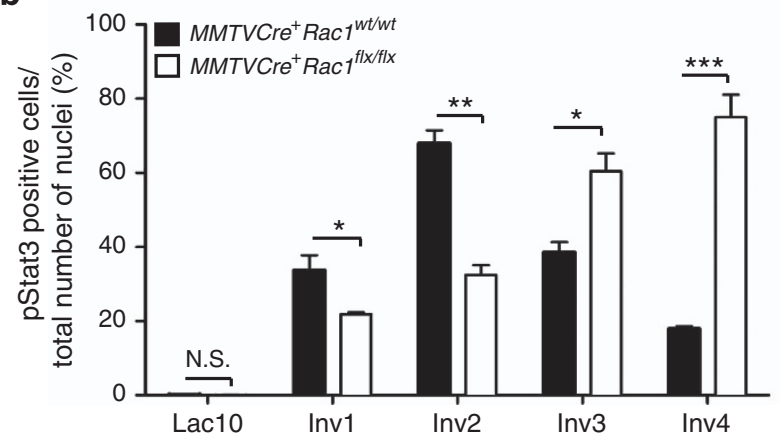

Figure 3 Stat 3 activation is delayed in the absence of Rac1 expression during involution. (a) $\mathrm{IHC}$ analysis showing $\mathrm{p}$-Stat 3 staining in mammary glands at 10 days of lactation and after 1, 2, 3 and 4 days of involution in MMTVCre ${ }^{+}$Rac $^{\text {wt }}{ }^{\text {wt }}$ and MMTVCre $^{+}$Ract $^{f l x f f x}$ mice (scale bar: $100 \mu \mathrm{m}, \times 20$ ). (b) Average number of the p-Stat3-positive MECs normalized by the total number of nuclei (\%) at the indicated

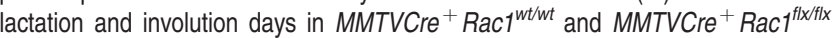
mice. Ten random sections were analyzed and quantified from each mouse $(n=3)$. Data were shown as mean \pm S.E.M. The indicated $P$-values are calculated by using a two-tailed Student's $t$-test. NS, not significant, ${ }^{*} P \leq 0.05$, ${ }^{* *} P \leq 0.01$ and ${ }^{* * *} P \leq 0.001$

animals (Figure 4a). We found a decrease in the levels of p-Stat3 at 1 and 2 days of involution in the absence of Dock1 expression (Figure 4a). Similar observations were made when p-Stat3 positive cells were analyzed by IF (Supplementary Figures S6 and 8). Quantification of the amount of p-Stat3positive cells normalized on the total number of nuclei further confirmed the initial delay observed in the activation of Stat3 when Dock1 is absent (Figure $4 \mathrm{~b}$ and Supplementary Figure S8). At Inv4, levels of $p$-Stat3 reached a maximum in mutant animals. These results indicate that Dock1 and Rac1 are required to activate Stat3 during involution. 

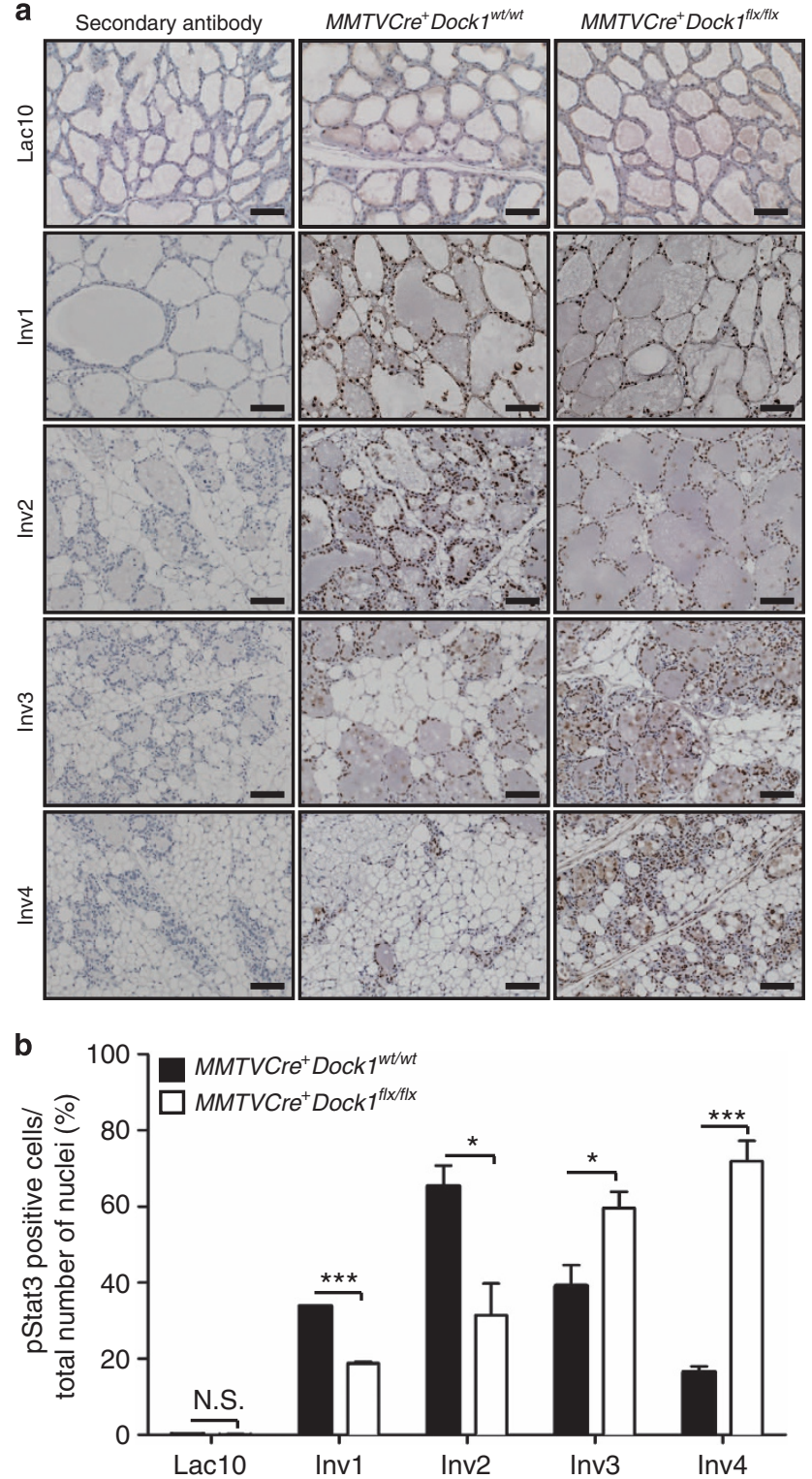

Figure 4 Stat3 activation is delayed in the absence of Dock1 expression during involution. (a) $\mathrm{IHC}$ analysis showing p-Stat 3 staining in mammary glands at 10 days of lactation and after 1, 2, 3 and 4 days of involution in MMTVCre ${ }^{+}$Dock $1^{\text {wt wt }}$ and MMTVCre ${ }^{+}$Dock $1^{f / x / f x}$ mice (scale bar: $100 \mu \mathrm{m}, \times 20$ ). (b) Average number of the p-Stat3-positive MECs normalized by the total number of nuclei (\%) at the indicated lactation and involution days in MMTVCre ${ }^{+}$Dock $1^{\text {wt }}{ }^{\text {twt }}$ and MMTVCre ${ }^{+}$Dock $1^{\text {flx }}$ fitx mice. Ten random sections were analyzed and quantified from each mouse $(n=3)$. Data were shown as mean \pm S.E.M. The indicated $P$-values are calculated by using a two-tailed Student's $t$-test. NS, not significant, ${ }^{*} P \leq 0.05$ and ${ }^{* \star} P \leq 0.001$

\section{Decreased cell death in the absence of Dock1/Rac1} signaling. A unique function of Stat3 is to induce cell death during involution. ${ }^{15,16}$ As Stat3 activation is delayed in both Rac1 and Dock1 mutant mice, we investigated whether cell death is also postponed. Activation of Stat3 promotes a lysosomal mode of cell death during the first phase of involution that does not require the activity of executioner caspases, but they are activated, and cleavage of caspase-3 can be used to measure levels of cell death. ${ }^{16}$ In agreement with the observed delay in Stat3 activation, staining of
MMTVCre ${ }^{+} \operatorname{Rac1}^{f l x / f l x}$ mammary glands during involution for cleaved caspase-3 (Figures $5 a$ and b) or terminal deoxynucleotidyl transferase dUTP nick-end labeling (TUNEL) (Supplementary Figures S9 and 10) revealed decreased cell death in the absence of Rac1 at Inv1-3. Similarly, quantification of the amount of cleaved caspase-3- (Figures $5 a$ and b) or TUNEL- (Supplementary Figures S9 and S10) positive cells revealed a significant increase in the number of dying cells in Rac1 mutants in comparison with control animals at Inv4. Identical results were obtained when caspase-3- (Figures 6a and b) or TUNEL- (Supplementary Figures S9 and S11) positive cells were quantified from the mammary gland of MMTVCre ${ }^{+}$Dock $1^{\text {wt } / w t}$ and MMTVCre ${ }^{+}$ Dock $1^{\text {flX/flx }}$ animals. These results suggest that Dock1 and Rac1 are required to induce maximal cell death during involution.

Dock1 and Rac1 contribute to the engulfment of dead corpses in epithelial cells. We hypothesize that Dock1 and Rac1 could contribute to dying cell clearance during involution. Because of the complexity of the in vivo phenotypes with respect to cell death initiation, we first addressed directly this issue by testing the requirement of Dock1 and Rac1 during engulfment by MECs. Normal murine mammary gland (NMuMG) epithelial cells were transfected with a CTRL siRNA or siRNAs targeting Rac1 or Dock1. Western blot analyses confirmed the downregulation of these proteins (Figures $7 \mathrm{a}$ and b). Following transfection, cells were presented with apoptotic thymocyte targets labeled with CFSE (Supplementary Figure S12). The engulfment of apoptotic targets was observed using confocal microscopy (Figure 7c) and the percentage of engulfed apoptotic thymocytes was quantified (Figure $7 \mathrm{~d}$ ). After $2 \mathrm{~h}$ of incubation, most apoptotic thymocytes were engulfed in CTRL cells. In contrast, only a small proportion of the thymocytes was engulfed by siRac1 or siDock1 NMuMG cells (Figure 7d). The same tendency was observed after $5 \mathrm{~h}$ of engulfment (data not shown). These results demonstrate that Dock1 and Rac1 are required to promote dying cell clearance by MECs in vitro.

To investigate if Dock1 and Rac1 contribute to removing superfluous cells in vivo, we stained late time points of involution for TUNEL for the presence of persistent dying cells. We found a significant accumulation of TUNEL-positive cells at Inv6 and Inv8 in Rac1 mutant mammary glands (Supplementary Figure S10). Likewise, a persistent detection of TUNEL-positive cells was observable at Inv8 in Dock1 mutant glands (Supplementary Figure S11). These data suggest that Dock1 and Rac1 contribute to promote dying cell clearance by MECs in vivo.

\section{Discussion}

Upon accumulation of milk in lactating mammary glands, the death of excessive epithelial cells is induced and these cells are promptly removed by neighboring epithelial cells and by infiltrating phagocytes. ${ }^{11,12,26}$ Mammary gland involution is essential to ensure that the tissue returns to a prepregnancy state and that it conserves its ability to initiate another cycle. Orthologs of Dock1, Elmo and Rac in C. elegans were 

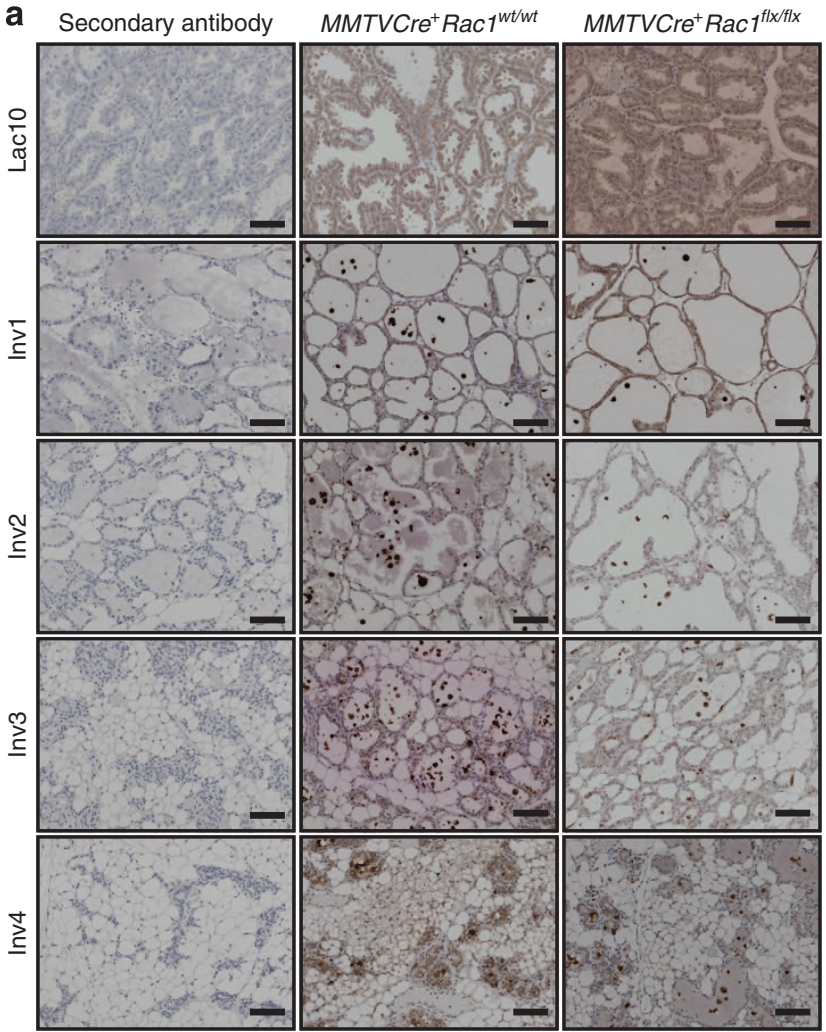

b

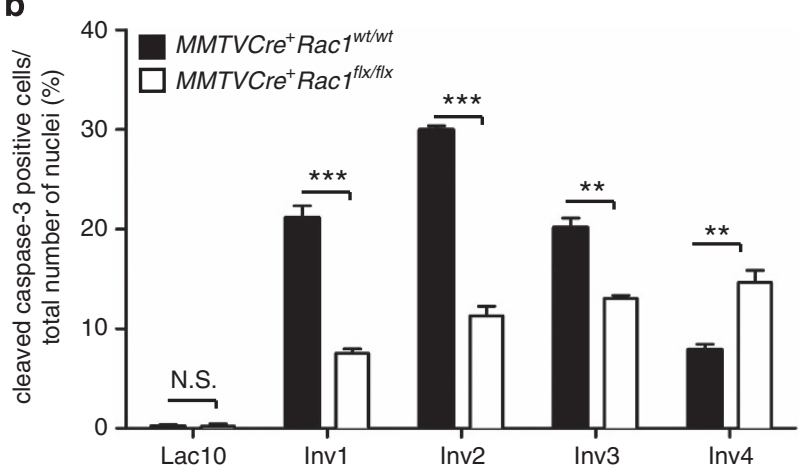

Figure 5 Cell death is decreased in the absence of Rac1 expression during involution. (a) $\mathrm{IHC}$ analysis showing cleaved caspase- 3 staining in mammary glands at 10 days of lactation and after $1,2,3$ and 4 days of involution in MMTVCre ${ }^{+}$ Rac1 $^{\text {wtiwt }}$ and MMTVCre ${ }^{+}$Rac1 $^{f / x / f i x}$ mice (scale bar: $\left.100 \mu \mathrm{m}, \times 20\right)$ (b) Average number of the cleaved caspase-3-positive MECs normalized by the total number of nuclei (\%) at the indicated lactation and involution days in MMTVCre ${ }^{+}$Rac1 ${ }^{\text {wtwt }}$ and MMTVCre $^{+}$Ract $^{f(x) f l x}$ mice. Ten random sections were analyzed and quantified from each mouse $(n=3)$. Data were shown as mean \pm S.E.M. The indicated $P$-values are calculated by using a two-tailed Student's $t$-test. NS, not significant, ${ }^{* \star} P \leq 0.01$ and ${ }^{* \star} P \leq 0.001$

described as part of a signaling module promoting engulfment. ${ }^{3}$ Here we investigated the role of Dock1 and Rac1 in the engulfment of dead corpses in mammals by using mammary gland involution as a model. While we revealed that Dock1 and Rac1 expression contribute in epithelial phagocytes to mediate dead cell clearance in vitro and in vivo, our studies unexpectedly revealed a role for Dock1 and Rac1 in the initiation of involution. Dock1-and Rac1-nullmammary glands failed to activate properly Stat3 such that a delay in the a Secondary antibody MMTVCre ${ }^{+}$Dock $1^{\text {wt/wt }}$ MMTVCre ${ }^{+}$Dock $1^{f \mid x / f l x}$

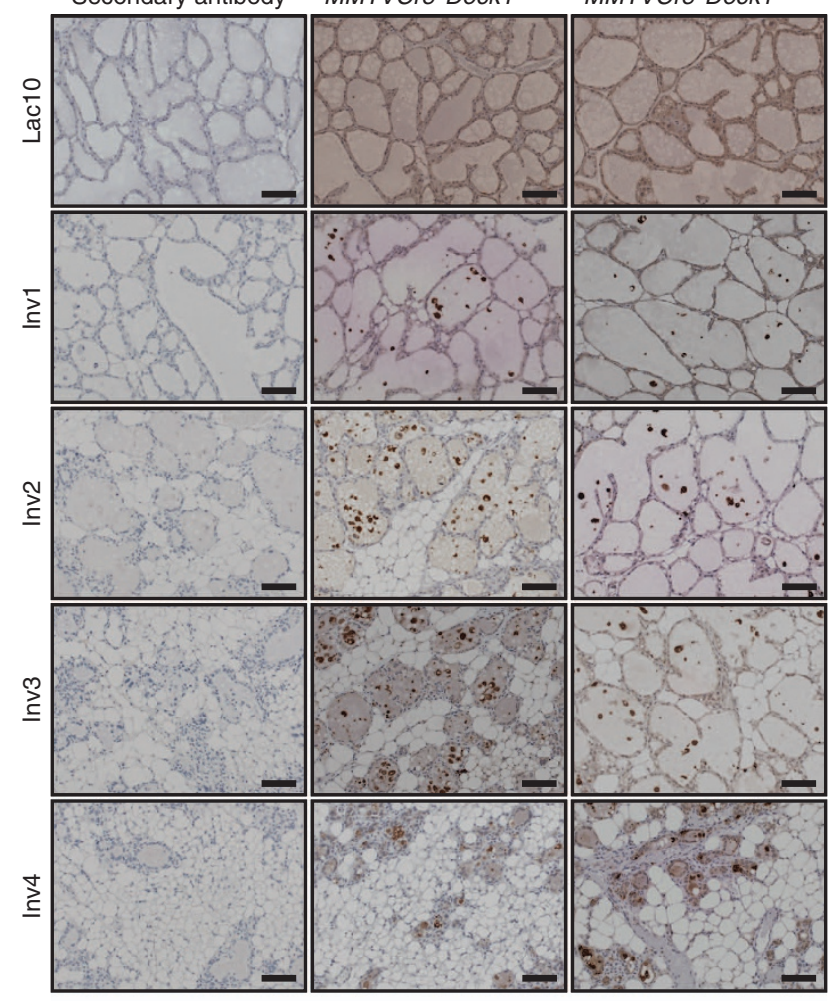

b

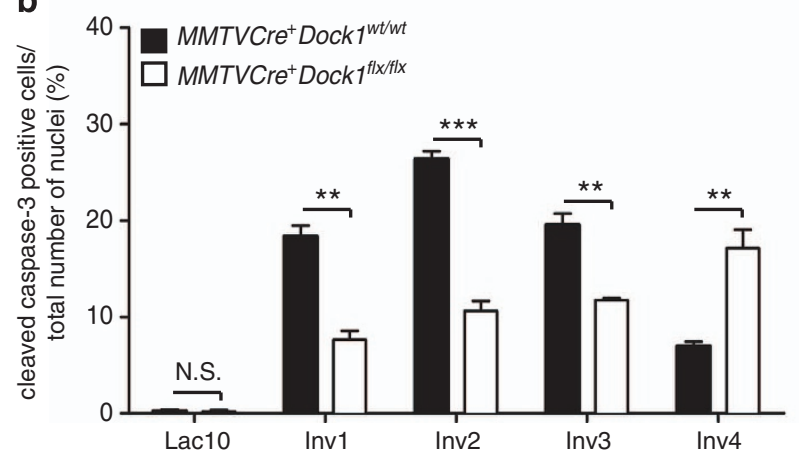

Figure 6 Cell death is decreased in the absence of Dock1 expression during involution. (a) IHC analysis showing cleaved caspase-3 staining in mammary glands at 10 days of lactation and after 1,2, 3 and 4 days of involution in MMTVCre Dock $1^{\text {wt } w t}$ and MMTVCre ${ }^{+}$Dock $1^{f / x f f x}$ mice (scale bar: $\left.100 \mu \mathrm{m}, \times 20\right)(\mathrm{b})$ Average number of the cleaved caspase-3-positive MECs normalized by the total number of nuclei $(\%)$ at the indicated lactation and involution days in MMTVCre ${ }^{+}$Dock $1^{\text {wtwt }}$ and $\mathrm{MMTVCre}^{+} \mathrm{Dock}^{\mathrm{fl} x \mathrm{fl} x}$ mice. Ten random sections were analyzed and quantified from each mouse $(n=3)$. Data were shown as mean \pm S.E.M. The indicated $P$-values are calculated by using a two-tailed Student's $t$-test. NS, not significant, ${ }^{* *} P \leq 0.01$ and ${ }^{* *} P \leq 0.001$

morphologic changes associated with involution was observed in mutant animals.

Most studies on Dock1 and Rac1 with respect to their roles in apoptosis focused on signaling in engulfing cells. However, inactivation of Dock1 or Rac1 promotes cell death in epiblasts. ${ }^{27}$ Likewise, downregulation of Dock1 in cardiomyocytes predisposes them to apoptosis. ${ }^{28}$ In contrast, our study highlights a role for Dock1 and Rac1 as proapoptotic proteins. A complex formed of CrkIl-Dock1 relocalizes to the nucleus to 


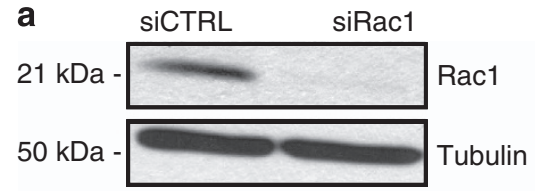

b

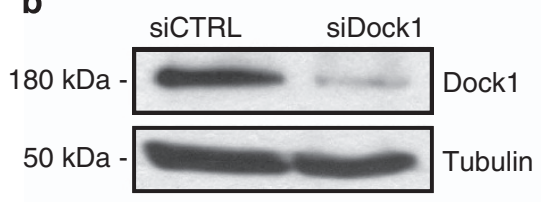

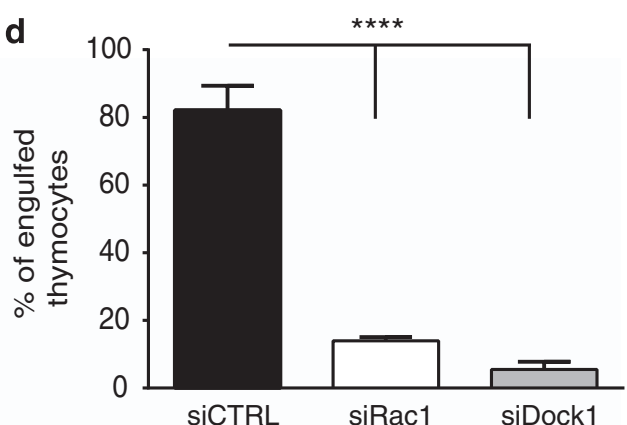

siRac1

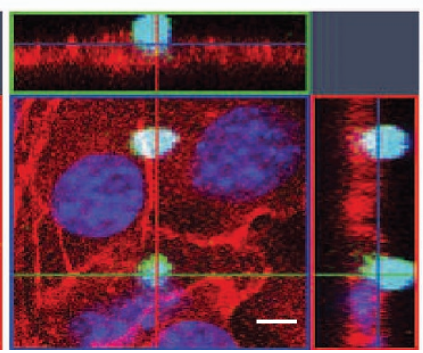

Phalloidin/Hoechst/CFSE

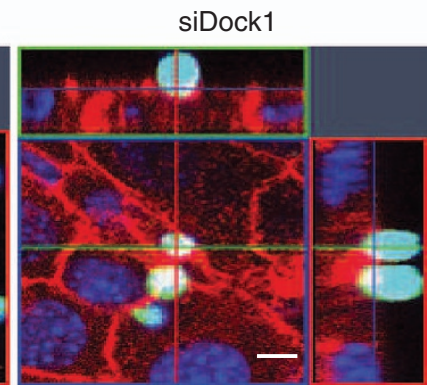

Figure 7 Phagocytosis of apoptotic cells by MECs requires Rac1 and Dock1 expression. (a) Western blot analysis demonstrating siRNA-mediated knockdown of Rac1 expression in NMuMG cells. (b) Western blot analysis demonstrating siRNA-mediated knockdown of Dock1 expression in NMuMG cells. (c) Representative confocal microscopy images showing defective engulfment of apoptotic thymocytes by NMuMG cells transfected with siRac1 and siDock1 (scale bar: $5 \mu$ m; red: phalloidin staining; blue: Hoechst; green: CFSE). (d) Average percentage of apoptotic thymocytes engulfed by NMuMG cells transfected with siCTRL, siRac1 and siDock1 after $2 \mathrm{~h}$ ( $n=3$ ). Data were shown as mean \pm S.D. The indicated $P$-values are calculated by using one-way ANOVA, followed by a Bonferroni's multiple comparisons test. ${ }^{* * * \star} P \leq 0.0001$

promote cell death in fibroblasts. ${ }^{29}$ Whether such a relocalization of Dock1 also occurs in predying MECs should be explored. The ability of a phagocyte to engage a preapoptotic cell is a required step for full execution of apoptosis; ${ }^{30}$ a possibility in our model is that impaired engulfment lengthens the survival of cells destined to die.

We observed that the delay in adipocyte repopulation during involution is more robust in Dock1 than in Rac1 mutant mammary glands. We speculate that Rac2 or Rac3 could be acting redundantly or could be compensating for the loss of Rac1. Further expression profiling and generation of double or triple Rac mutants could confirm this hypothesis. Likewise, it is possible that Dock5 in part compensates for the loss of Dock1; we reported a genetic interaction between these RacGEFs during myoblast fusion. ${ }^{31}$

Stat3 is both an orchestrator of mammary gland involution and an inducer of cell proliferation and invasion in breast cancer cells. ${ }^{25}$ This transcription factor is classically activated downstream of a variety of receptors including cytokines receptors, growth factor receptors and G-protein-coupled receptors. Although the mechanisms still remain unclear, signaling by Rac contributes to Stat 3 activation. ${ }^{32}$ Binding of the MgcRacGAP/Rac1 complex to Stat3 promotes Stat3 phosphorylation on $\mathrm{Y}^{705} \cdot{ }^{33} \mathrm{MgcR}$ acGAP is also proposed to work as a nuclear chaperone and facilitates nuclear translocation of the MgcRacGAP/Rac1/Stat3 complex..$^{34}$ Moreover, cadherin engagement was reported to increase the levels of activated Rac1 that promotes IL-6 production. In this context, signaling by Rac acts upstream of IL- 6 production and indirectly contributes to Stat 3 activation. ${ }^{35}$ We previously reported that Stat3 activation in small mammary gland neoplasic lesions induced by HER2 is reduced in the absence of Dock1. ${ }^{22}$ Here, we observed that Stat3 activation at the onset of involution is diminished in the absence of Rac1 and Dock1. We propose that Dock1 is an important GEFactivating Rac1 and promoting Stat3 activation in both physiologic and pathologic conditions. It will be important to identify the molecular intermediates that act upstream/downstream of Dock1/Rac1 to connect to Stat3 signaling pathway during mammary gland involution and breast cancer. One candidate that could relay the signals induced by milk accumulation to Dock1/Rac1/Stat3 is p130Cas. It was previously shown that mechanical stretching of cells at focal adhesion induced a conformational change in p130Cas that allow sensing of the mechanical force to be converted into a biochemical signaling. ${ }^{36}$ Through its binding with the adaptor protein Crk, p130Cas forms a complex with Dock1 and could relay mechanical stimuli to Rac1. ${ }^{37}$ As milk is proposed to induce mechanical stretching in the duct, it will be interesting to investigate the contribution of p130Cas to mammary gland involution. A previous study revealed that overexpressing p130Cas in the mammary gland induced a delay in mammary gland involution. ${ }^{38}$

Our study also revealed that Dock1/Rac1 signaling is required in epithelial phagocytes to promote engulfment of dead cells. This is the first study to address and demonstrate a possible conservation of the function of Dock1 in the clearance of dead cells in mammals. Although we observed an accumulation of apoptotic cells in late involution time points in Dock1/Rac1 glands, it is possible that professional 
phagocytes have infiltrated the remodeling glands to assist the epithelial cells in the removal of dying cells. The Dock1binding partner Elmo1 was previously shown to act downstream of the PtdSer receptor Bai1 to promote clearance of apoptotic cells and Elmo1 mutant animals have a defect in the clearance of apoptotic germ cells in the testis. ${ }^{8,9}$ It will remain to be determined whether Bai1 is expressed and required by epithelial cells to promote activation of the Dock1/Elmo1/Rac1 module to induce clearance of dead epithelial cells during mammary gland involution. Alternatively, other phagocytic receptors such as integrins or Tyro3, Axl or MerTK could be critical to clear dying cells through Dock1/Rac1 signaling. Interestingly, MerTK inactivation, but not AXL-Tyro3 double deletion, prevents prompt clearance of dying MECs. ${ }^{39}$ Genetic inactivation of the integrin ligand Mfge8, which decorates dying MECs, leads to involution defects. ${ }^{20,21}$ Dock1 operates downstream of this receptor-ligand module to promote engulfment by immature dendritic cells. ${ }^{6}$ Inactivation of genes coding for autophagy proteins, Becn and Atg7, impairs clearance of dying MECs during involution; it was reported that Mgfe8-binding integrin Itgb5 and MerTK are poorly expressed in these mouse models, explaining impaired removal of dead corpses. ${ }^{40}$ The exact receptors using the Dock1/Rac pathway for clearance of dying MECs remain to be established.

We previously observed that higher levels of Dock1 expression are associated with a worst prognosis in basal and HER2-positive breast cancer patients and showed that the HER2 oncogene uses Dock1 to promote breast cancer progression. $^{22}$ Several studies highlighted that the mammary gland stroma is prometastatic during involution and epidemiology studies suggest that the period surrounding pregnancy is transiently associated with an increase risk of breast cancer. ${ }^{41,42}$ Breast cancer is still the most common cancer in women worldwide; therefore, a better comprehension of the molecular mechanisms regulating all aspects of the mammary gland life cycle could provide important insights into the mechanisms that mediate tumorigenesis.

\section{Materials and Methods}

Mice strains and animal care. Rac $f^{f(x) f l x}$ mice were acquired from Jackson

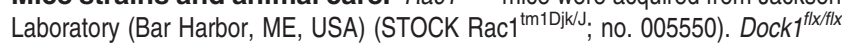
mice were generated in our laboratory and described previously. ${ }^{22}$ Transgenic MMTVCre $^{+}$mice were described previously. ${ }^{43}$ All mouse experiments were conducted according to the Canadian Council of Animal Care rules and were previously approved by the Institut de Recherches Cliniques de Montréal Animal Care Committee.

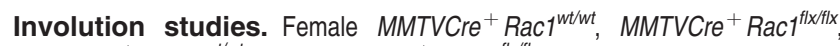

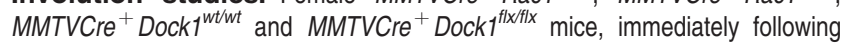
the first pregnancy and ongoing lactation, were used for involution studies. Pups were allowed to suckle for 10 days postpartum and were then removed from the cage to force mammary gland involution. The mammary glands were collected at either Lac10 or after 1, 2, 3 or 4 days following pups removal (Inv1, Inv2, Inv3 and Inv4). At the time of analysis, the right-side fourth mammary glands (Mg4) was collected, fixed in 4\% paraformaldehyde (PFA), paraffin embedded, sectioned at $5 \mu \mathrm{m}$ for IHC analysis and stained with H\&E for histologic analysis, while the rightside second mammary gland (Mg2) was collected for the protein study.

Adipocyte repopulation. Sections of mammary glands at Lac10 or Inv1-4 of involution were stained with $\mathrm{H} \& \mathrm{E}$. Adipocytes were also stained by immunohistochemistry with an anti-Perilipin2 antibody (see below). Average percentage of the area occupied by adipocytes was quantified using the ImageJ software.
Immunohistochemistry. Paraffin-embedded sections were deparaffinized in xylene for $20 \mathrm{~min}$, and rehydrated in decreasing concentrations of ethanol, $100 \%, 95 \%, 90 \%, 70 \%$ and $50 \%$ respectively. They were then washed three times in phosphate-buffered saline $(1 \times \mathrm{PBS})$ and subjected to antigen retrieval in $10 \mathrm{mM}$ sodium citrate $\left(\mathrm{pH} \mathrm{6.0)}\right.$ or $1 \mathrm{mM}$ EDTA $(\mathrm{pH} 8.0)$ at $95^{\circ} \mathrm{C}$. Endogenous peroxide activity was blocked by incubation in $3 \%$ hydrogen peroxide and sections were washed with PBS, permeabilized with PBSTT $(1 \times$ PBS, $0.5 \%$ Triton X-100 and $0.02 \%$ Tween), blocked in PBSTT, $1 \%$ bovine serum albumin (BSA) at RT and were then incubated with primary antibody diluted in PBSTT 1\% BSA overnight. Sections were washed three times in PBSTT and incubated with secondary antibody diluted in PBSTT 1\% BSA. They were then washed three times in PBSTT, incubated with tertiary antibody diluted in PBSTT 1\% BSA and washed three times in $1 \times$ PBS. Antigen localization of washed sections was performed with DAB Peroxidase Substrate Kit (no. SK 4100; Vector Laboratories, Burlington, ON, Canada).

Immunofluorescence. Paraffin-embedded sections were deparaffinized in xylene for $20 \mathrm{~min}$, and rehydrated in decreasing concentrations of ethanol, $100 \%$, $95 \%, 90 \%, 70 \%$ and $50 \%$ respectively. They were then washed three times in PBS and subjected to antigen retrieval in $1 \mathrm{mM}$ EDTA (pH 8.0) at $95^{\circ} \mathrm{C}$. Sections were washed with PBS, permeabilized with PBSTT, blocked in PBSTT 1\% BSA at $\mathrm{RT}$ and were incubated with primary antibody diluted in PBSTT 1\% BSA overnight. Sections were washed three times in PBT (PBS $(1 \times), 0.2 \%$ Triton X-100) and incubated with secondary antibody diluted in BBT (PBT, 1\% BSA) for $30 \mathrm{~min}$. They were then washed three times in PBT and incubated with Alexa Fluor 633 phalloidin (5:200 dilution) (A22284; Invitrogen, Burlington, ON, Canada) in PBT for $30 \mathrm{~min}$, followed by three washes with PBT. Hoechst (33342, Invitrogen) was applied to fluorescently labeled sections and a coverslip was sealed using nail polish. Images were taken using a Zeiss LSM710 confocal microscopy (Carl Zeiss, Toronto, ON, Canada) and analyzed using the Zen 2009 software (Carl Zeiss).

Whole-mount analysis of mammary glands. Whole-mount analyses of mammary glands were realized as described elsewhere. ${ }^{22}$ Briefly, Mg4s from MMTV-Cre ${ }^{+}$Rac1 $^{\text {wtiwt }}$ and MMTV-Cre ${ }^{+}$Ract $^{\text {flx } / f \mid x}$ mice at 9,12 and 15 weeks of puberty or Mg4s from MMTVCre ${ }^{+}$Rac1 $^{\text {wt/wt }}$, MMTVCre $^{+}$Racf $^{f(x) f l x}$, MMTVCre ${ }^{+}$

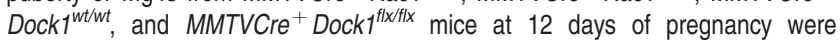
collected, fixed in $4 \%$ PFA, washed with $70 \%$ ethanol, defatted two times with acetone and stained in carmine red solution overnight. Tissues were rehydrated in increasing concentrations of ethanol, $70 \%, 95 \%$ and $100 \%$ respectively. They were then cleared in xylene and mounted with Permount (no. SP15-500; Fisher, Ottawa, ON, Canada). Main and side branches from the duct were quantified from each virgin mammary gland by counting each branch in the mammary gland section as described elsewhere. ${ }^{44}$ Alveolar lobules were quantified from each pregnant mammary gland at 12 days of pregnancy.

Cell culture and siRNA transfection. NMUMG cells were grown in DMEM supplemented with $10 \%$ (vol/vol) FBS, 2 mM L-glutamine, $20 \mathrm{mM}$ HEPES (pH 7.4), $10 \mu \mathrm{g} / \mathrm{ml}$ insulin and penicillin/streptomycin. NMuMG cells at $70 \%$ of confluence were transfected with siCTRL, siDock1 or siRac1 (180 nM; siGENOME Smartpool Dharmacon, Lafayette, LA, USA) using Lipofectamine 2000.

Western blot analyses. Total tissue extracts from mammary glands were prepared as described elsewhere. ${ }^{45}$ Briefly, frozen mammary glands were homogenized using a tissue grinder (no. 358003; Wheaton, Millville, NJ, USA) in $2 \mathrm{ml}$ extraction buffer ( $25 \mathrm{mM}$ Tris $(\mathrm{pH} 7.4), 150 \mathrm{mM} \mathrm{NaCl})$. They were then centrifuged and fat was removed from the supernatant. The homogenates were next lysed in Radio ImmunoPrecipitation Assay (RIPA) buffer $(50 \mathrm{mM}$ Tris $(\mathrm{pH}$ 7.5), $0.1 \%$ SDS, $0.5 \%$ deoxycholic acid, $1 \%$ Nonidet P- $40,150 \mathrm{mM} \mathrm{NaCl}, 5 \mathrm{mM}$ EDTA). NMuMG cells were directly lysed in RIPA. Equal amount of proteins were subjected to SDS-PAGE and proteins of interest were detected by immunoblotting as described previously. ${ }^{46}$

Phagocytosis assay and microscopy. Thymus from 5-week-old mice were dissected, cut into small pieces, transferred into a culture dish containing RPMI, 10\% FBS and washed two times with the same medium. Freshly isolated thymocytes were then incubated with $10 \mu \mathrm{M}$ dexamethasone (no. D2915; SigmaAldrich, Oakville, ON, Canada) at $37^{\circ} \mathrm{C}$ for $6 \mathrm{~h}$ in RPMl containing $10 \%$ FBS to induce apoptosis. Annexin V-FITC/propidium iodide (PI) staining was performed to evaluate apoptosis levels. Apoptotic thymocytes $\left(2 \times 10^{6}\right.$ cells) were labeled with CFSE (no. C34554; Invitrogen) according to the manufacturer's instructions. 
CFSE-labeled apoptotic thymocytes were then added to $5.0 \times 10^{4} \mathrm{NMuMG}$ cells transfected with siCTRL, siDock1 or siRac1 that were replated in four-well culture slides at $24 \mathrm{~h}$ posttransfection (no. 354104; BD Biosciences) and reached $50 \%$ confluence. Apoptotic targets were incubated with epithelial cells for $2 \mathrm{~h}$ to allow phagocytosis. Cells were washed gently with $1 \times$ PBS, fixed in $4 \%$ PFA for $10 \mathrm{~min}$, washed three times with PBT and blocked with BBT overnight. They were washed three times with PBT, incubated with Alexa Fluor 633 phalloidin (5:200 dilution) (A22284; Invitrogen) in PBT for $30 \mathrm{~min}$, followed by three washes with PBT. Hoechst (33342; Invitrogen) was applied to fluorescently labeled sections and a coverslip was sealed using nail polish. Images were taken using a Zeiss LSM710 confocal microscopy (Carl Zeiss) and analyzed using the Zen 2009 software (Carl Zeiss).

Antibodies for immunohistochemistry, IF and western blotting. Antibodies used for IHC were as follows: Perilipin (1:100; no. 3470S; Cell Signaling Technology, Danvers, MA, USA), p-Stat3 ${ }^{\text {Y705 }}$ (1:100; no. 9145S; Cell Signaling Technology), cleaved caspase-3 (1:200; no. 9661S; Cell Signaling Technology), p-Stat5 ${ }^{Y 694}$ (1:200; no. 9314S; Cell Signaling Technology). Antibodies used for IF were as follows: p-Stat3 ${ }^{\text {Y705 }}$ (1:100; no. 9145S; Cell Signaling Technology). Antibodies used for western blotting were as follows: Rac1 (1:3000; no. 05-389; Upstate Biotechnology, Lake Placid, NY, USA); Dock1 (1:1000; no. sc-6043; Santa Cruz Biotechnology, Dallas, TX, USA); tubulin (1:10000; no. T5168; Sigma-Aldrich); p-Stat3 ${ }^{\text {Y705 }}$ (1:100; no. 9145S; Cell Signaling Technology), Stat3 (1:5000; no. 9132S; Cell Signaling Technology).

RNA isolation and RT-PCR from mammary gland tissues. Total RNA from mammary gland tissues was extracted using RNeasy Mini Kit (no. 74104; Qiagen) according to the manufacturer's instructions. The purity of the RNA samples was determined by visualizing intact $18 \mathrm{~S}$ and $28 \mathrm{~S}$ rRNA bands by agarose gel electrophoresis. One microgram of total RNA was used for each sample and cDNA synthesis was carried out using M-MuLV Reverse Transcriptase (M0253S; New England Biolabs) according to the manufacturer's instructions. Primers for RT-PCR were as follows: Rac1 (forward: $5^{\prime}$-CTGAAGTGCGACACCACTGT-3' and reverse: $5^{\prime}$-CTTGAGTCCTCGCTGTGTGA-3'); Dock1 (forward: $5^{\prime}$-GGCCTACACTTTGCTTCTGC-3' and reverse: 5'-TACTGCTCCGCAAGTT CCTT-3'); and $\beta$-Actin (forward: $5^{\prime}$-GGCTGTATTCCCCTCCATCG- $3^{\prime}$ and reverse: 5'-CCAGTTGGTAACAATGCCATGT-3').

TUNEL assay. Paraffin-embedded mammary gland tissues were subjected to TUNEL assay using DeadEnd Fluorometric TUNEL System Kit (no. G3250; Promega, Madison, WI, USA). Briefly, paraffin-embedded sections were deparaffinized in xylene for $20 \mathrm{~min}$, and rehydrated in decreasing concentrations of ethanol, $100 \%, 95 \%, 90 \%, 70 \%$ and $50 \%$, respectively. Sections were washed in $0.85 \% \mathrm{NaCl}$ for $5 \mathrm{~min}$, rinsed in PBS for $5 \mathrm{~min}$, fixed in $4 \%$ PFA for $10 \mathrm{~min}$ and washed again with PBS for $5 \mathrm{~min}$. The liquid from the tissue section was removed and $100 \mu$ l of the $20 \mu \mathrm{g} / \mathrm{ml}$ Proteinase $\mathrm{K}$ solution was added onto each section and incubated for $10 \mathrm{~min}$ at RT. Sections were then washed with PBS, fixed in $4 \%$ PFA for $10 \mathrm{~min}$ and washed again with PBS. Sections were then incubated with $100 \mu \mathrm{l}$ of equilibration buffer for $10 \mathrm{~min}$. The liquid was removed and was incubated with $50 \mu \mathrm{l}$ of $\mathrm{rTdT}$ incubation buffer at $37^{\circ} \mathrm{C}$ for $60 \mathrm{~min}$ inside a humidified chamber covered with aluminum foil. Sections were then washed with $2 \times$ SSC (saline-sodium citrate) buffer for $15 \mathrm{~min}$ at RT to stop the reaction, and then rinsed three times in PBS. Hoechst (33342, Invitrogen) was applied to sections and a coverslip was sealed using nail polish. Images were taken using a Zeiss LSM710 confocal microscopy (Carl Zeiss) and analyzed using Zen 2009 software (Carl Zeiss).

\section{Conflict of Interest}

The authors declare no conflict of interest.

Acknowledgements. We thank Dr Morag Park and Dr Josie Ursini-Sigel for critical reading of the manuscript. We also thank Dr I Rhee and Dr A Veillette for their help with the phagocytosis assays. This work was funded by grants from the Canadian Cancer Society (no. 19104) and CIHR (MOP-77591) to JFC. WJM is a recipient of a Canada Research Chair in Molecular Oncology. ML was supported by a scholarship of $U$ Montréal and $\mathrm{JH}$ was a recipient of an Invitrogen-IRCM scholarship. JFC is a recipient of a Senior Investigator Award from Fonds de Recherche du Québec-Santé.

1. Fuchs $Y$, Steller H. Programmed cell death in animal development and disease. Cell 2011; 147: $742-758$.
2. Elliott MR, Ravichandran KS. Clearance of apoptotic cells: implications in health and disease. J Cell Biol 2010; 189: 1059-1070.

3. Reddien PW, Horvitz HR. The engulfment process of programmed cell death in Caenorhabditis elegans. Annu Rev Cell Dev Biol 2004; 20: 193-221.

4. Albert ML, Kim JI, Birge RB. alphavbeta5 integrin recruits the Crkll-Dock180-rac1 complex for phagocytosis of apoptotic cells. Nat Cell Biol 2000; 2: 899-905.

5. Gumienny TL, Brugnera E, Tosello-Trampont AC, Kinchen JM, Haney LB, Nishiwaki K et al. CED-12/ELMO, a novel member of the Crkll/Dock180/Rac pathway, is required for phagocytosis and cell migration. Cell 2001; 107: 27-41.

6. Akakura S, Singh S, Spataro M, Akakura R, Kim Jl, Albert ML et al. The opsonin MFG-E8 is a ligand for the alphavbeta5 integrin and triggers DOCK180-dependent Rac1 activation for the phagocytosis of apoptotic cells. Exp Cell Res 2004; 292: 403-416.

7. Tosello-Trampont AC, Kinchen JM, Brugnera E, Haney LB, Hengartner MO, Ravichandran KS. Identification of two signaling submodules within the CrkII/ELMO/Dock180 pathway regulating engulfment of apoptotic cells. Cell Death Differ 2007; 14: 963-972.

8. Park D, Tosello-Trampont AC, Elliott MR, Lu M, Haney LB, Ma Z et al. BAl1 is an engulfment receptor for apoptotic cells upstream of the ELMO/Dock180/Rac module. Nature 2007; 450: 430-434.

9. Elliott MR, Zheng S, Park D, Woodson RI, Reardon MA, Juncadella IJ et al. Unexpected requirement for ELMO1 in clearance of apoptotic germ cells in vivo. Nature 2010; 467: 333-337.

10. Lu Z, Elliott MR, Chen Y, Walsh JT, Klibanov AL, Ravichandran KS et al. Phagocytic activity of neuronal progenitors regulates adult neurogenesis. Nat Cell Biol 2011; 13: 1076-1083.

11. Watson CJ, Kreuzaler PA. Remodeling mechanisms of the mammary gland during involution. Int J Dev Biol 2011; 55: 757-762.

12. Monks J, Smith-Steinhart C, Kruk ER, Fadok VA, Henson PM. Epithelial cells remove apoptotic epithelial cells during post-lactation involution of the mouse mammary gland. Biol Reprod 2008; 78: 586-594.

13. O'Brien J, Martinson H, Durand-Rougely C, Schedin P. Macrophages are crucial for epithelial cell death and adipocyte repopulation during mammary gland involution. Development 2012; 139: 269-275.

14. Lund LR, Romer J, Thomasset N, Solberg H, Pyke C, Bissell MJ et al. Two distinct phases of apoptosis in mammary gland involution: proteinase-independent and -dependent pathways. Development 1996; 122: 181-193.

15. Chapman RS, Lourenco PC, Tonner E, Flint DJ, Selbert S, Takeda K et al. Suppression of epithelial apoptosis and delayed mammary gland involution in mice with a conditional knockout of Stat3. Genes Dev 1999; 13: 2604-2616.

16. Kreuzaler PA, Staniszewska AD, Li W, Omidvar N, Kedjouar B, Turkson J et al. Stat3 controls lysosomal-mediated cell death in vivo. Nat Cell Biol 2011; 13: 303-309.

17. Tiffen PG, Omidvar N, Marquez-Almuina N, Croston D, Watson CJ, Clarkson RW. A dual role for oncostatin $\mathrm{M}$ signaling in the differentiation and death of mammary epithelial cells in vivo. Mol Endocrinol 2008; 22: 2677-2688.

18. Kritikou EA, Sharkey A, Abell K, Came PJ, Anderson E, Clarkson RW et al. A dual, nonredundant, role for LIF as a regulator of development and STAT3-mediated cell death in mammary gland. Development 2003; 130: 3459-3468.

19. Schere-Levy C, Buggiano V, Quaglino A, Gattelli A, Cirio MC, Piazzon I et al. Leukemia inhibitory factor induces apoptosis of the mammary epithelial cells and participates in mouse mammary gland involution. Exp Cell Res 2003; 282: 35-47.

20. Atabai K, Fernandez R, Huang X, Ueki I, Kline A, Li Y et al. Mfge8 is critical for mammary gland remodeling during involution. Mol Biol Cell 2005; 16: 5528-5537.

21. Hanayama R, Nagata S. Impaired involution of mammary glands in the absence of milk fat globule EGF factor 8. Proc Natl Acad Sci USA 2005; 102: 16886-16891.

22. Laurin M, Huber J, Pelletier A, Houalla T, Park M, Fukui $Y$ et al. Rac-specific guanine nucleotide exchange factor DOCK1 is a critical regulator of HER2-mediated breast cancer metastasis. Proc Natl Acad Sci USA 2013; 110: 7434-7439.

23. Reichenstein M, Rauner G, Barash I. Conditional repression of STAT5 expression during lactation reveals its exclusive roles in mammary gland morphology, milk-protein gene expression, and neonate growth. Mol Reprod Dev 2011; 78: 585-596.

24. Wagner M, Bjerkvig R, Wiig H, Dudley AC. Loss of adipocyte specification and necrosis augment tumor-associated inflammation. Adipocyte 2013; 2: 176-183.

25. Resemann HK, Watson CJ, Lloyd-Lewis B. The Stat3 paradox: a killer and an oncogene. Mol Cell Endocrinol 2013; 382: 603-611.

26. Watson CJ. Involution: apoptosis and tissue remodelling that convert the mammary gland from milk factory to a quiescent organ. Breast Cancer Res 2006; 8: 203.

27. He X, Liu J, Qi Y, Brakebusch C, Chrostek-Grashoff A, Edgar D et al. Rac1 is essential for basement membrane-dependent epiblast survival. Mol Cell Biol 2010; 30: 3569-3581.

28. Yan A, Li G, Zhang X, Zhu B, Linghu H. Pro-survival effect of Dock180 overexpression on rat-derived H9C2 cardiomyocytes. Med Sci Monit Basic Res 2013; 19: 12-19.

29. Kar B, Reichman CT, Singh S, O'Connor JP, Birge RB. Proapoptotic function of the nuclear Crk II adaptor protein. Biochemistry 2007; 46: 10828-10840.

30. Reddien PW, Cameron S, Horvitz HR. Phagocytosis promotes programmed cell death in C. elegans. Nature 2001; 412: 198-202.

31. Laurin M, Fradet N, Blangy A, Hall A, Vuori K, Cote JF. The atypical Rac activator Dock180 (Dock1) regulates myoblast fusion in vivo. Proc Natl Acad Sci USA 2008; 105: 15446-15451. 
32. Raptis L, Arulanandam R, Geletu M, Turkson J. The R(h)oads to Stat3: Stat3 activation by the Rho GTPases. Exp Cell Res 2011; 317: 1787-1795.

33. Tonozuka Y, Minoshima Y, Bao YC, Moon Y, Tsubono Y, Hatori T et al. A GTPaseactivating protein binds STAT3 and is required for IL-6-induced STAT3 activation and for differentiation of a leukemic cell line. Blood 2004; 104: 3550-3557.

34. Kawashima T, Bao YC, Minoshima Y, Nomura Y, Hatori T, Hori T et al. A Rac GTPaseactivating protein, MgcRacGAP, is a nuclear localizing signal-containing nuclear chaperone in the activation of STAT transcription factors. Mol Cell Biol 2009; 29: 1796-1813.

35. Arulanandam R, Vultur A, Cao J, Carefoot E, Elliott BE, Truesdell PF et al. Cadherin-cadherin engagement promotes cell survival via Rac1/Cdc42 and signal transducer and activator of transcription-3. Mol Cancer Res 2009; 7: 1310-1327.

36. Sawada Y, Tamada M, Dubin-Thaler BJ, Cherniavskaya O, Sakai R, Tanaka S et al. Force sensing by mechanical extension of the Src family kinase substrate p130Cas. Cell 2006; 127: 1015-1026.

37. Kiyokawa $E$, Hashimoto $Y$, Kurata $T$, Sugimura $H$, Matsuda M. Evidence that DOCK180 up-regulates signals from the Crkll-p130(Cas) complex. J Biol Chem 1998; 273: 24479-24484.

38. Cabodi S, Tinnirello A, Di Stefano P, Bisaro B, Ambrosino E, Castellano I et al. p130Cas as a new regulator of mammary epithelial cell proliferation, survival, and HER2-neu oncogene-dependent breast tumorigenesis. Cancer Res 2006; 66: 4672-4680.

39. Sandahl M, Hunter DM, Strunk KE, Earp HS, Cook RS. Epithelial cell-directed efferocytosis in the post-partum mammary gland is necessary for tissue homeostasis and future lactation. BMC. Dev Biol 2010; 10: 122

40. Teplova I, Lozy F, Price S, Singh S, Barnard N, Cardiff RD et al. ATG proteins mediate efferocytosis and suppress inflammation in mammary involution. Autophagy2013: 9: 459-475.

41. McDaniel SM, Rumer KK, Biroc SL, Metz RP, Singh M, Porter W et al. Remodeling of the mammary microenvironment after lactation promotes breast tumor cell metastasis. Am J Pathol 2006; 168: 608-620.
42. Lambe M, Hsieh C, Trichopoulos D, Ekbom A, Pavia M, Adami HO. Transient increase in the risk of breast cancer after giving birth. N Engl J Med 1994; 331: 5-9.

43. Andrechek ER, Hardy WR, Siegel PM, Rudnicki MA, Cardiff RD, Muller WJ. Amplification of the neu/erbB-2 oncogene in a mouse model of mammary tumorigenesis. Proc Natl Acad Sci USA 2000; 97: 3444-3449

44. Ensslin MA Shur BD. The EGF repeat and discoidin domain protein, SED1/MFG-E8, is required for mammary gland branching morphogenesis. Proc Natl Acad Sci USA 2007; 104: 2715-2720.

45. Ackler S, Ahmad S, Tobias C, Johnson MD, Glazer RI. Delayed mammary gland involution in MMTV-AKT1 transgenic mice. Oncogene 2002; 21: 198-206.

46. Komander D, Patel M, Laurin M, Fradet N, Pelletier A, Barford D et al. An alpha-helical extension of the ELMO1 pleckstrin homology domain mediates direct interaction to DOCK180 and is critical in Rac signaling. Mol Biol Cell 2008; 19: 4837-4851.

Cell Death and Disease is an open-access journal published by Nature Publishing Group. This work is licensed under a Creative Commons Attribution-NonCommercialShareAlike 3.0 Unported License. The images or other third party material in this article are included in the article's Creative Commons license, unless indicated otherwise in the credit line; if the material is not included under the Creative Commons license, users will need to obtain permission from the license holder to reproduce the material. To view a copy of this license, visit http://creativecommons.org/licenses/ by-nc-sa/3.0/

Supplementary Information accompanies this paper on Cell Death and Disease website (http://www.nature.com/cddis) 